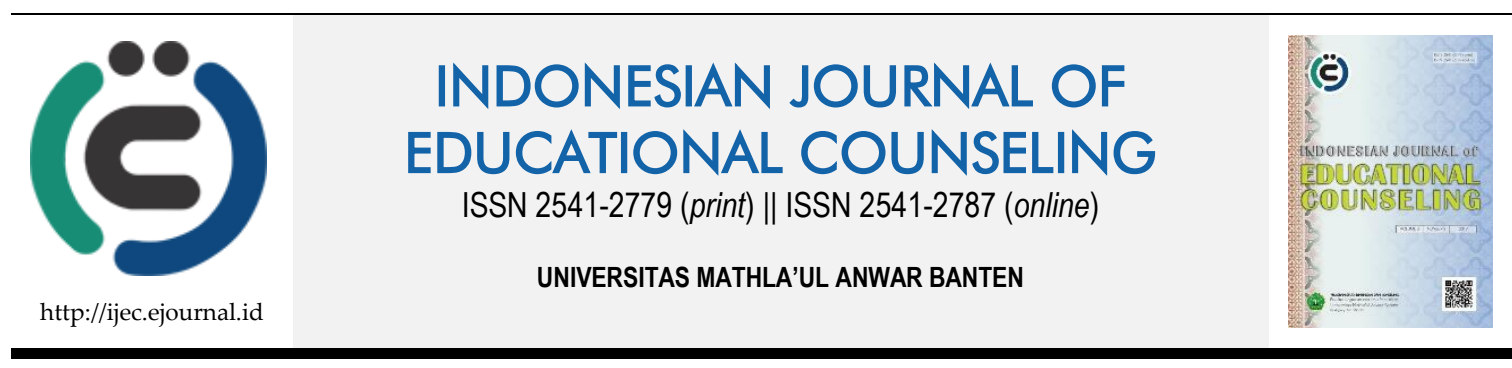

Research Based Article

\title{
Perceived Problems of Strike Action and Deviant Behavior at Selected Higher Institutions of Ekiti State, Nigeria
}

\author{
Yusuf Suleiman ${ }^{1}$, Muraina Kamilu Olanrewaju², Jamiu Mahmood Suleiman ${ }^{3}$ \\ ${ }^{1}$ Unicaf University, ${ }^{2}$ Al-Hikmah University, Nigeria ${ }^{3}$ Kwara State College of Arabic and Islamic Legal Studies
}

\begin{tabular}{|c|c|}
\hline Article History & ABSTRACT \\
\hline $\begin{array}{l}\text { Received: } 13.01 .2019 \\
\text { Received in revised form: } \\
23.04 .2019 \\
\text { Accepted: } 17.06 .2019 \\
\text { Available online: } 16.07 .2019\end{array}$ & $\begin{array}{l}\text { This study aimed to investigate the perceived problems of strike action and } \\
\text { deviant behavior in selected higher institutions in Ekiti State, Nigeria. The } \\
\text { descriptive research design of ex-post-facto type was used in the study. Three } \\
\text { hundred respondents were selected randomly from two Universities. The } \\
\text { respondents were measured with a self-developed scale, and the data obtained } \\
\text { were analyzed using descriptive (mean) statistical analysis. Four research } \\
\text { questions were raised and answered. The result showed that causes of strike } \\
\text { action in selected higher institutions include non-payment of teacher's salaries, } \\
\text { low responds to problems confronting schools among others, problems of strike } \\
\text { action in selected higher institutions include production of half-baked } \\
\text { graduates, youth involvement in secret cult, widespread of examination } \\
\text { malpractice, causes of deviant behavior in selected higher institutions include } \\
\text { parental neglect, drug addiction, high level of poverty among others and } \\
\text { problems of deviant behavior in selected higher institutions include incessant } \\
\text { strike action, widespread of examination malpractice, prevalence of teenage } \\
\text { pregnancy among others. Given these findings, the study recommended that } \\
\text { school counselors should identify deviant behaviors and counsel adolescents } \\
\text { on how it can be prevented and that Government should deem it fit to respond } \\
\text { to the yearnings and aspirations of the workers in terms of quick payment of } \\
\text { their salaries and other emoluments. }\end{array}$ \\
\hline
\end{tabular}

KEYWORDS: Deviant Behavior, Higher Institutions, Strike Action.

DOI: $10.30653 / 001.201932 .78$

(C) (1)

This is an open access article distributed under the terms of the Creative Commons Attribution 4.0 International License, which permits unrestricted use, distribution, and reproduction in any medium, provided the original work is properly cited. ๑) 2019 Yusuf Suleiman, Muraina Kamilu Olanrewaju, Jamiu Mahmood Suleiman.

\section{INTRODUCTION}

Education has been generally accepted to be the backbone of every nation. A country that is blessed with abundant educationists and intellectuals will indeed reach the apex of any form of development, be it political, scientific, technological, economical among others. However, no single individual can attain the height of any educational achievement without passing through the school. In passing through the school, one has to be imparted with knowledge by the teachers and lecturers of different levels of

${ }^{1}$ Corresponding author’s address: Unicaf University, Old International Airport, 7130 Larnaca, Cyprus; Email: y.suleiman@unicaf.org 
education (Aliu, 1999). The importance of education in any economy is enormous. It is acknowledged that education has a positive relationship with economic growth and development and that the development of nations in the 21st century depends on the quality and quantity of his level of education in different countries. Education is a way of life which goes on all the time in different societies. It is the most significant investment in human resources and can be appropriately earned through a positive attitude to its rudiments, which include adequate attendance and completion of acts process. It may be planned, or unplanned noticed or unnoticed, but is always influenced by external and internal stimuli.

A strike action (or simply a strike) is when a large number of workers stop working in protest. Strikes are usually done by a labor union to get better pay, hours, or working conditions. They became prominent during the industrial revolution when many worked in factories and mines. In many countries, it is against the law to strike. In other countries, people who strike are protected under certain conditions (Banjo, 1989). Strikes or industrial actions by workers tend to be frequent in Nigeria. Although plagued by leadership struggles, ideological differences, and regional ethnic conflicts, the Nigerian Labor Congress has been able to organize or threaten nationwide workers' strikes, demanding the retention of government subsidies on petroleum products, minimum wages, and improved working conditions.

It is quite a pity that despite 15 years of civilian government in Nigeria today, no succeeding government has been able to find a lasting solution to the recurrence of strikes by university workers in Nigeria (Jamiu, 2014). In addition, Dayo (2012) emphasized that if various educational levels be it primary, secondary most essential universities in Nigeria are nowhere to be found in the ranking of top 1,000 universities in the world, it may not be only because of inadequate funding but also because of large chunks of academic years that university academic staff are on strike for legitimate reasons when they could be contributing scholarly growth that would propel our institutions into the lists of some of the best in the world. A strike usually takes place in response to employee grievances. In most countries, strike actions were made illegal. Most western countries partially legalized striking in the late 19th or early 20th centuries. Currently, Nigeria has witnessed several regimes in terms of his political administrations. These administrations have actively intervened in labor-management relations through the use of incomes policies and labor decrees in an attempt to control the state of industrial relations (Okuwa \& Campbell, 2011). Despite governments' intervention in labor-management relations, unions are still very much autonomous. Several studies have emerged in the last few decades on the issue of strike and wage negotiation. These studies show that labor disputes and union militancy are often perceived to have political overtones, even though the overwhelming majority of the strikes are in the private sector due to collective negotiations in which economic grievances are the underlying factors (Jegede, 1989; Otobo, 1984). Other studies of strikes in Nigeria (Olaniyi, 1991; Otobo 1984; Osang, 2002) showed that the Nigerian government has been and continues to be an active participant in wage determination and price movement since wage and price variables are significant explanatory variables in any strike action.

Furthermore, the damage that strikes actions by teachers has done to education sector in the last couple of years is difficult to quantify, where teachers are forced to go on strike for improved welfare package so that they can also meet their social obligations to themselves, families and the larger society, thus resulting in situations where students are 
left on their own to wonder about for the period of the strike (Kolawole, 2012). Also during this period, some idled students may engage themselves in social vices including joining bad gangs and engagement in internet fraud while others students might die in road accidents during the period of the strike in an attempt to "stretch their legs" to visit friends to kill the idleness. Not a few cases of pregnancy of students during the period of the strike have been reported (Okebukola, 1999). Frequent strikes also affect the psychology; growth and development of most students because they could not finish their degree at the right time; thus, the students' loss focus and lack motivation for studies. As a result, most parents who do not want their children to join the lousy gang and lose focus had to spend more money to maintain their children/wards (Okuwa \& Campbell, 2011). It is worth emphasizing that any government with a weak education system is heading towards a black future. At the same time, the various unions in our schools and institutions of higher learning should device other means other than strike to resolve aggrieved issues. Strike action should be the last resort. This is because of the negative effect frequent strikes have on students and the entire academic community.

Deviant behavior, as used in this study, encompasses those behaviors that are offensive in society. It has a scenario in Nigeria society, most notably among the youth (Adolescent). Good moral characters that use to be in school are no more there. Lack of respect for elders, changes in social values, less respect for authority, increase in family breakdown, increase in class sizes, unskilled parenting is a significant influence, and other forms of vices are now observable in the society. There is no gainsaying, the fact that a lot of the factors influencing adolescents' adjustment to school and society can be traced to their various homes. The primary causative agent of deviant behavior is the home because every individual comes from a family to form a school or society (Adewole, 1990). Ndem (1988) stressed that when couples are separated or divorced, the training of the children is at the mercy of the maladjusted parents. There is a higher tendency for sex delinquency when children grow under one parent except when they stay more frequently with their uncle. He further noted that if the family has no moral code for the children, there will be a high risk of delinquency. The absence of recreational facilities like indoor games and few readily available outdoor games may influence delinquency.

Similarly, Jamiu (2013) observed that deviant behavior in adolescents could result from fear of violence, truancy, absenteeism, or a condition that make both teaching and learning difficult. Location of the school can also contribute to the development of deviant behavior among the youth. In line with this, Chauhen (1988) added that, if the school is located far off city or in an industrial area, near cinema house, market place, children may be tempted to engage in delinquent acts. Furthermore, the problem of deviant behavior in school is a subset of more general behaviors in the larger society in which the school exists. Inadequate supply of facilities can be a basis for deviant behavior. Such facilities like libraries, science laboratory, workshop equipment, resource persons, and sport in school may negatively engage students mind in bad behaviors (Aliu, 1994). He stressed further that the following points cause deviant behavior and invariably falling in educational standard in secondary schools e.g., inadequate of educational material for institutions, too much external influence, insufficient attention to student's welfare and rapid increase in the enrolment of students. Jimoh (1990) maintained that, in Nigeria today, money is everything, and the average Nigerian will do anything to get money. It is the end that justifies the means. In the school setting, pupils and college students employ all sorts of devilish means to pass examinations since the society regard certificate as the only 
passport to a good life. What youth watch on television, read in papers (mass media) also contributes to the causes of deviant behavior.

Educational institutions have a significant share in the problems of strike action and deviant behavior in Nigerian higher institutions. Odediran (1999) noted that there is no doubt in the fact that the contemporary education system in Nigeria is facing many problems among which include strike action and deviant behavior and examination malpractice at the private and public institutions to mention a few. Similarly, Bakare (1994) observed that indiscipline and strike action disturbs effective teaching and learning. Omotosho (2007) added that there is quite a full spread belief that the standard of discipline and learning are falling or have fallen in most Nigeria educational institutions. The phenomenon of a secret cult is another dimension destroying the social-academic lives in Universities, Polytechnics, and Colleges of Education all over the country (Sumanu, 1999). It reaches its peak when risk factors such as dysfunctional family, extreme economic deprivations, lack of connectedness to adult role models and poor neighborhoods outweigh the protective causes, and risky behaviors become more frequent and previous. Any society where truancy, deviant, smoking, alcoholism, drug addiction, pick-pocketing, lateness, bribery, vandalization of public properties, and examination malpractice is characterized as unstable and indiscipline society. Bad behavior spread quickly in schools as well as in society, which needs to be handled appropriately. It can be seen from the above that what is happening in society today is suggesting a fearful future for this great nation. As such, the current study intends to fill the gaps in the previous study and more to the existing literature by investigating the perceived problems of strike action and deviant behavior in selected higher institutions in Ekiti State, Nigeria.

\section{METHOD}

The research design used in this study is descriptive research design of ex-post-facto. It was employed to ascertain the perceived problems of strike action and deviant behavior in selected higher institutions without manipulations. However, it carefully observed and recorded information as it naturally occurred at the time the study was conducted. The population for the study comprised of all undergraduate students in Ekiti State, Nigeria. The sample for this study consists of 89,801 participants who were randomly selected from undergraduate students in Ekiti State. Multi-stage sampling technique was used in selecting the participants. The first stage involves the use of stratified random sampling to put the universities in the state into two (state and federal). The second stage witnessed a random selection of three faculties in each university. Thirdly, two departments were randomly selected in each faculty. In each chosen randomly department, 25 students were selected through balloting. On the whole, 312 university undergraduate students were selected for the study. This consists of both male and female and across different ages.

A self-developed instrument tagged "Perceived Problems of Strike Action and Deviant behavior in Selected Higher Institutions Scale (PPSADBSHIS)" was used to assess the participants. The instrument has 3 sections A, B and C. Section A deals with sociodemographic information about the participants, section B consists of 10 items to elicit information on problems of strike action and section $C$ consists of 10 items to elicit information on problems of deviant behavior of the participants. The instrument was based on a 4-point scale, which includes Strongly Agree ( $\mathrm{SA}=4)$; Agree $(\mathrm{A}=3)$; Disagree 
( $\mathrm{D}=2$ and Strongly Disagree (SD =1). For content and face validity of the instruments designed for the study, the researcher gave the instruments to experts in the field of Education and experts in the area of Research and Statistics. After all these people had given their suggestions and made necessary correction on the instrument, the researcher then made the final corrections on the instrument. After content and face validity of the instruments, twenty (20) copies of the instruments were administered to higher institutions in Osun State who were not part of the studied population in order to reestablish the psychometric properties of the instrument. The test re-test analysis of reliability was then used to test their reliability to ensure that they are consistent in measuring what they were designed to measure. The results from the analysis carried out yielded 0.82 reliability value.

The instruments were administered to the participants in the departments/classrooms for the exercise. The researchers were assisted by research assistants in the administration and collection of the instruments. In each higher institution, the administration and collection of instruments were done on the same day of administration. Out of 312 instruments distributed, only 300 were filled correctly and were collated for data analysis. Descriptive (Mean) statistical analysis was used in analyzing the data.

\section{RESULT AND DISCUSSION}

This study has a research question raised and answered in the study: 1) What are the causes of strike action in selected higher institutions in Nigeria? 2) What are the problems of strike action in selected higher institutions in Nigeria? 3) What are the causes of deviant behavior in selected higher institutions in Nigeria? 4) What are the problems of deviant behavior in selected higher institutions in Nigeria?

\section{The Causes of Strike Action at Selected Higher Institutions in Nigeria}

The causes of strike action in selected higher institutions which include non-payment of teachers salaries, poor workers welfare, inconsistence government policy, low response to problems confronting schools among others with mean values above the average of 1.50. While the items with mean scores below 1.50 remain unimportant factors that cause strike action in higher institutions. Table 1 shows that non-payment of teacher's salaries, poor workers welfare, inconsistence government policy, low response to problems confronting schools among others are causes of the strike in selected higher institutions.

The first research question indicated the causes of strike action in selected higher institutions. That is like include non-payment of teacher's salaries, poor workers welfare, inconsistence government policy, low response to problems confronting schools among others are causes of the strike in selected higher institutions. The result is in line with the study of Jegede (1989) and Otobo (1983) who found that labor disputes and union militancy are often perceived to have political overtones, even though the overwhelming majority of the strikes are in the private sector. Due to collective negotiations in which economic grievances are the underlying factors. It is quite a pity that despite 15 years of civilian government in Nigeria today, no succeeding government has been able to find a lasting solution to the recurrence of strikes by university workers in Nigeria (Jamiu, 2014). 
Table 1: Rank Order Analysis on the Causes of Strike Action in Selected Higher Institutions

\begin{tabular}{llll}
\hline S/N & Strike action are caused by: & Mean & Rank \\
\hline 1 & Nonpayment of teachers salaries & 1.60 & 1 st \\
2 & Poor workers welfare & 1.56 & 2nd \\
3 & $\begin{array}{l}\text { Inconsistence in government policy towards development of } \\
\text { education }\end{array}$ & 1.55 & 3rd \\
& Low responds of government to problems confronting schools & 1.50 & 4 th \\
4 & Nonpayment of teachers benefits as at when due & 1.49 & 5 th \\
5 & Enrolment of non qualified personnel into higher institution & 1.48 & 6 th \\
6 & Lack of necessary facilities and teaching aids in schools & 1.45 & 7 th \\
7 & Lack of provision of well-trained teacher in schools system. & 1.44 & 8th \\
9 & Bad economic situation. & 1.42 & 9 th \\
10 & Inadequate distribution of education facilities in schools. & 1.40 & 10th \\
\hline
\end{tabular}

Dayo (2012) found that if various educational levels be it primary, secondary most essential universities in Nigeria are nowhere to be found in the ranking of top 1,000 universities in the world, it may not be only because of inadequate funding but also because of large chunks of academic years that university academic staff are on strike for legitimate reasons when they could be contributing scholarly growth that would propel our institutions into the lists of some of the best in the world. Despite governments' intervention in labor-management relations, unions are still very much autonomous. Other studies of strikes in Nigeria (Olaniyi, 1991; Otobo 1984; Osang, 2002) showed that the Nigerian government has been and continues to be an active participant in wage determination and price movement since wage and price variables are significant explanatory variables in any strike action.

\section{The Problems of Strike Action at Selected Higher Institutions in Nigeria}

The problems of strike action in selected higher institutions which include production of half-baked graduates, youth involvement in secret cult, widespread of examination malpractice in school and prevalence of teenage pregnancy among others with mean values above average of 1.50 . While the items with mean scores below 1.50 remain unimportant factors that serve as problems to strike action in higher institutions. It was however concluded that production of half-baked graduates, youth involvement in secret cult, widespread of examination malpractice in school and prevalence of teenage pregnancy among others are problems of strike action in selected higher institutions. The details are shown in Table 2.

Table 2: Rank Order Analysis on the Problems of Strike Action in Selected Higher Institutions

\begin{tabular}{llll}
\hline S/N & Effects of Strike action are by: & Mean & Rank \\
\hline 1 & Production of half-baked graduates & 1.57 & 1 st \\
2 & Youth involvement in secret cult. & 1.53 & 2nd \\
3 & Widespread of examination malpractice in school. & 1.51 & 3rd \\
4 & Prevalence of teenage pregnancy & 1.50 & 4 th \\
5 & Bad/poor peer influence on students & 1.44 & 5 th \\
6 & Youths engagement in drug addiction & 1.37 & 6 th \\
7 & Exposure of youths to negative information from the media & 1.35 & 7 th \\
8 & Increase in poverty rate & 1.28 & 8 th \\
9 & Parent associating their children with drugs. & 1.27 & 9 th \\
10 & Destruction of school facilities & 1.19 & 10 th \\
\hline
\end{tabular}


The second research question indicated the problems of strike action in selected higher institutions. That is like include the production of half-baked graduates, youth involvement in a secret cult, widespread of examination malpractice in school and prevalence of teenage pregnancy among others are problems of strike action in selected higher institutions. That result is in collaboration with the finding of Kolawole (2012) who found that the damage that strikes actions by teachers has done to the education sector in the last couple of years is difficult to quantify.

Because of the situation above, the teachers are forced to go on strike for improved welfare package, so that they can also meet their social obligations to themselves, families, and the larger society. That matter was resulting in situations where students are left on their own to wonder about for the period of the strike. Also, during this period, some idled students may engage themselves in social vices, including joining bad gangs and engagement in internet fraud. Meanwhile, other students might die in road accidents during the period of the strike in an attempt to "stretch their legs" to visit friends to kill the idleness (Okebukola, 1999). Frequent strikes also affect the psychology; growth and development of most students because they could not finish their degree at the right time; thus, the students' loss focus and lack motivation for studies. As a result, most parents who do not want their children to join the lousy gang and lose focus had to spend more money to maintain their children/wards (Okuwa \& Campbell, 2011).

\section{The Causes of Deviant Behavior at Selected Higher Institutions in Nigeria}

The causes of deviant behavior in selected higher institutions which include parental neglect, involvement in secret cult, drug addiction, parental rejection, high level of poverty, exposure of youths to negative information from the media among others with mean values above average of 1.50 . While the items with mean scores below 1.50 remain unimportant factors that causes deviant behavior in higher institutions. Table 3 shows that parental neglect, involvement in secret cult, drug addiction, parental rejection, high level of poverty, exposure of youths to negative information from the media among others are causes of deviant behavior in selected higher institutions. The third research question demonstrated the causes of deviant behavior in selected higher institutions which include parental neglect, involvement in a secret cult, drug addiction, parental rejection, high level of poverty, exposure of youths to negative information from the media among others are causes of deviant behavior in selected higher institutions.

That results above are in support with the finding of Ndem (1988 who found that when couples are separated or divorced, the training of the children is at the mercy of the maladjusted parents. There is a higher tendency for sex delinquency when children grow under one parent except when they stay more frequently with their uncle. He further noted that if the family has no moral code for the children, there will be a high risk of delinquency. The absence of recreational facilities like indoor games and few readily available outdoor games may influence delinquency. Lack of respect for elders, changes in social values, less respect for authority, increase in family breakdown, increase in class sizes, unskilled parenting is a significant influence, and other forms of vices are now observable in the society. There is no gainsaying, the fact that a lot of the factors influencing adolescents' adjustment to school and society can be traced to their various 
homes. The primary causative agent of deviant behavior is the home because every individual comes from a family to form a school or society (Adewole, 1990).

Table 3: Rank Order Analysis on the Causes of Deviant Behavior in Selected Higher Institutions

\begin{tabular}{llll}
\hline S/N & Causes of Deviant behavior are by: & Mean & Rank \\
\hline 1 & Parental neglect of children & 3.20 & 1st \\
2 & Youth involvement in secret cult & 3.17 & 2nd \\
3 & Drug addiction & 3.11 & 3rd \\
4 & Parental rejection & 2.99 & 4 th \\
5 & High level of poverty & 2.97 & 5 th \\
6 & Constant exposure of youths to negative information from the media & 2.96 & 6 th \\
7 & Bad peer influence & 1.46 & 7 th \\
8 & Widespread of examination malpractice in school & 1.44 & 8 th \\
9 & Lack of provision of well-trained teacher in schools system & 1.42 & 9 th \\
10 & Broken home & 1.39 & 10th \\
\hline
\end{tabular}

\section{The Problems of Deviant Behavior at Selected Higher Institutions in Nigeria}

Table 4 indicated the problems of deviant behavior in selected higher institutions which include incessant strike action, destruction of school facilities, widespread of examination malpractice, prevalence of teenage pregnancy, peer influence, youth's engagement in drug addiction among others with mean values above average of 1.50 . While the items with mean scores below 1.50 remain unimportant factors that serve as problems of deviant behavior in higher institutions. It was however concluded that include incessant strike action, destruction of school facilities, widespread of examination malpractice, prevalence of teenage pregnancy, peer influence, youth's engagement in drug addiction among others are problems of deviant behavior in selected higher institutions.

Table 4: Rank Order Analysis on the Problems of Deviant Behavior in Selected Higher Institutions

\begin{tabular}{llll}
\hline S/N & Problems of Deviant behavior are by: & Mean & Rank \\
\hline 1 & Incessant strike action in the school & 2.42 & 1st \\
2 & Destruction of school facilities & 2.37 & 2nd \\
3 & Widespread of examination malpractice in school. & 2.31 & 3rd \\
4 & Prevalence of teenage pregnancy & 2.29 & 4 th \\
5 & Bad/poor peer influence on students & 2.27 & 5 th \\
6 & Youths engagement in drug addiction & 2.26 & 6 th \\
7 & Loss of human and material resources in the school & 1.39 & 7 th \\
8 & Increase in poverty rate & 1.36 & 8th \\
9 & Increase in fear and tension & 1.33 & 9 th \\
10 & Youth involvement in secret cult & 1.29 & 10th \\
\hline
\end{tabular}

The fourth research question indicated the problems of deviant behavior in selected higher institutions which incessant strike action, destruction of school facilities, widespread of examination malpractice, the prevalence of teenage pregnancy, peer influence, youth's engagement in drug addiction among others are problems of deviant behavior in selected higher institutions. This is in collaboration with the finding of Jamiu (2013) who found that deviant behavior in adolescents can result to fear of violence, truancy, absenteeism or a condition that make both teaching and learning difficult. 
Chauhen (1988) found that if the school is located far off the city or in an industrial area, near the cinema house, market place, children may be tempted to engage in delinquent acts. Furthermore, the problem of deviant behavior in school is a subset of more general behaviors in the larger society in which the school exists. Inadequate supply of facilities can be a basis for deviant behavior. Such facilities like libraries, science laboratory, workshop equipment, resource persons, and sport in school may negatively engage students mind in bad behaviors (Aliu, 1994). Jimoh (1990) maintained that, in Nigeria today, money is everything, and the average Nigerian will do anything to get money. It is the end that justifies the means. In the school setting, pupils and college students employ all sorts of devilish means to pass examinations since the society regard certificate as the only passport to a good life.

\section{CONCLUSION}

The result also implies that there is a great need to identify the causes and problems of strike action and deviant behavior in higher institutions. Therefore, the counselors, teachers and parents need to understand the adolescent very well. The result indicate that parental neglect of children, youth involvement in secret cult, bad peer influence, drug addiction and low responds of government to problems confronting schools are the most pressing problems of strike action and deviant behavior. It is the aim of every higher institution to assist students to grow up with a clear and acceptable view of what is right and wrong. Students learn by example as well as rule. Teachers along with parents have a substantial responsibility in setting a good example. Their task is complicated because it is their example which student follows. But schools can and do make a difference. They have the capacity to lead, support and encourage students in developing good behaviors and in learning to play a responsible role within the school and in the wider world. School foster goods behaviors and play vital role in promoting the spiritual, cultural, social, moral and physical development of young people. The ethos of the school should include a clear vision of important values held by the school and local community. The result also implies that there is a great need to identify the causes of strike action and deviant behavior with a way to find lasting solutions to the cancer worm. However, the government, various agencies, labor organizations, teachers, parents and students need to understand the various causes and problems of strike action and deviant behavior in all sectors especially the educational sector.

\section{REFERENCES}

Adewole, O. (1990). Secondary education in Nigeria. Ibadan: Abi Print and Pak Ltd.

Aliyu, D. (1994). A lecture note presented to the level three Islamic studies students. Unpublished manuscript. Kano: Department of Education of Bayero University, Nigeria.

Aliyu, D. (1999). Contemporary issues in Nigeria education. A paper presented during launching of UBE at Sokoto, Nigeria.

Bakare, C. G. M. (1994). Mass failure in public examinations: Some psychological perspectives: Monograph. Ibadan: Department of Guidance and Counselling, University of Ibadan, Nigeria. 
Banjo, O. (1989). Academic values clarification as a group counseling technique with student. Journal of Research in Counseling Psychology, 1, 89-93.

Chauhan, S. S. (1988). Advance educational psychology. New York: Van Educational press Ltd.

Dayo, A. (2012). Incessant ASSU strike: Bane of education. Retrieved July 20, 2018, from https://www.vanguardngr.com/2012/08/incessant-asuu-strikes-bane-of-educationsector.

Jamiu, M. S. (2013). Development of Education in Nigeria (Unpublished PDE Lecture note). College of Arabic and Islamic Legal Studies, Ilorin, Nigeria.

Jamiu, M. S. (2014). Prevention of deviant behavior (Unpublished lecture note for EDD 0237). College of Arabic and Islamic legal studies Ilorin, Nigeria.

Jegede, J. C. (1989). Effect of achievement motivation and study habits on English language performance of secondary school students (Unpublished Ph.D. thesis). University of Ilorin, Nigeria.

Jimoh, S. A. (1990). Discipline in school: A book of readings. Ilorin: Atoto Press Ltd.

Kolawole, S. O. (2012). The effect of mastery learning strategy and counseling on academic achievement of students in chemistry. The National Journal of Guidance and Counseling, 1(2), 97-107.

Ndem, M. C. (1988). A manual of educational psychology. Jos: God's grace press.

Odediran, N. O. (1999). Student counseling as a panacea for curbing examination malpractices in colleges of education in Nigeria. Education Digest, 1(48), 15-25.

Okebukola, A. O. (1999). The Nigerian education system: Past, present and future. Lagos: Thomas Nelson Nig Ltd.

Okuwa, O. B and Campbell, O. A. (2011). The Influence of Strike on the Choice of Higher Education Demand in Oyo State, Nigeria. Journal of Emerging Trends in Economics and Management Sciences (JETEMS),2(4), 275-280.

Olaniyi N. A. (1991). Relationship between study habits and academic performance of secondary school students in Irewole local government area of Oyo state (Unpublished Ph.D. thesis). University of Ilorin, Nigeria.

Omotosho, J. A. (2007). Principles of interpersonal relationships (Additional class notes on EGC 673). Ilorin: Department of Counseling Education of University of Ilorin.

Osang, W. (2002). The trade unions and their impact on university education in Nigeria (Unpublished M.Ed thesis). Department of Adult Education of University of Ibadan, Nigeria.

Otobo, D. (1984). Collective bargaining Myth and Reality. The Nigerian Journal of Economic and Social Studies, 26, 247-70.

Sumanu, B. S. (1999). Counseling centre in college of education. A Proposal Nigeria Education Digest, 1(4), 135-140. 